\title{
Strategi Bersaing Agen Perjalanan Konvensional Di Era Digital: Studi Pada PT. Jasa Nusa Wisata
}

\author{
Adhitya Bayu Suryantara \\ Prodi Akuntansi Fakultas Ekonomi dan Bisnis Universitas Mataram \\ adhityabayus@unram.ac.id
}

Received: 15 November, 2019; Accepted: 20 November, 2019; Published: 23 Desember, 2019

\begin{abstract}
Abstrak
Lahirnya agen perjalanan berbasis aplikasi (online travel agent / OTA) seperti traveloka, tiket.com dan pegi-pegi tidak hanya merubah gaya hidup orang dalam mengagendakan perjalanannya. Lebih jauh, OTA bahkan mampu mendisrupsi cara berbisnis yang dijalankan agen perjalanan konvensional. Hal ini menyebabkan timbulnya persaingan yang semakin ketat dalam industri agen perjalanan yang melibatkan agen perjalanan konvensional dan agen perjalanan berbasis aplikasi (OTA). Kondisi ini perlu disikapi oleh perusahaan dengan melakukan inovasiinovasi yang berkelanjutan untuk menghasilkan produk-produk yang memiliki nilai tambah. Agar dapat terus berinovasi, perumusan strategi bersaing menjadi perlu untuk dilakukan agar dapat memetakan posisi perusahaan di dalam industri yang selanjutnya diikuti dengan penyusunan program-program inovatif untuk dapat menjaga keberlangsungan perusahaan sesuai kondisi yang ada. Penelitian ini sendiri merupakan penelitian studi kasus yang bertujuan untuk merumuskan strategi bersaing alternatif dengan menggunakan analisis IFE, analisis EFE, serta analisis Matriks SWOT yang dikombinasikan dengan Matriks IE. Objek dalam penelitian ini adalah PT. Jasa Nusa Wisata yang berada di Pulau Lombok. Dari hasil analisis Matrilks IE diketahui bahwa PT. Jasa Nusa Wisata berada pada kuadran II yang berarti strategi paling tepat dalam posisi ini adalah investasi atau pengembangan secara selektif. Berdasarkan informasi tersebut, selanjutnya dirumuskan sepuluh strategi alternatif dengan menggunakan analisis SWOT yang secara garis besar merangkum kegiatan investasi dan pengembangan secara selektif.
\end{abstract}

Kata Kunci: Agen Perjalanan; Strategi Bersaing; Matriks IE; Matriks SWOT

\begin{abstract}
The rise of an application-based travel agent (online travel agent / OTA) such as traveloka, Tiket.com and pegi-pegi not only changes people's lifestyles in scheduling their trips. Furthermore, OTA is even able to disruptive the way business is carried out by conventional travel agents. This has led to increasingly fierce competition in the travel agent industry involving conventional travel agents and application-based travel agents (OTA). This condition needs to be addressed by companies by making continuous innovations to produce products that have added value. In order to continue to innovate, the formulation of a competitive strategy needs to be done in order to map the company's position in the industry which is then followed by the preparation of innovative programs to be able to maintain the company's sustainability in accordance with existing conditions. This research itself is a case study research that aims to formulate alternative
\end{abstract}


competitive strategies using IFE analysis, EFE analysis, and SWOT Matrix analysis combined with IE Matrix. The object of this research is PT. Jasa Nusa Wisata wich is located on the Lombok island. From the results of IE Matrilks analysis it is known that PT. Jasa Nusa Wisata is in quadrant II which means the most appropriate strategy in this position is investment or selective development. Based on this information, ten alternative strategies were then formulated using a SWOT analysis that broadly summarizes investment activities and selective development

Keywords: Travel Agencies; Competitive Strategy; IE Matrix; SWOT Matrix

\section{PENDAHULUAN}

Lahirnya agen perjalanan berbasis aplikasi (online travel agent / OTA) seperti traveloka, tiket.com dan pegi-pegi tidak hanya merubah gaya hidup orang dalam mengagendakan perjalanannya. Lebih jauh, OTA tersebut bahkan mampu mendisrupsi cara berbisnis yang dijalankan agen perjalanan konvensional. Berbagai informasi perjalanan dan pariwisata yang sebelumnya hanya dapat diperoleh melalui agen perjalanan, saat ini dapat diakses melalui perangkat yang lekat dengan aktivitas sehari-hari seperti smartphone dan laptop (Harsanti dkk., 2017; Anjastantri dan Dewantara, 2017). Para traveler tidak perlu lagi beranjak dari tempatnya, cukup dengan mengoperasikan aplikasi yang telah disediakan oleh OTA, skedul perjalanan, tempat menginap hingga metode pembayaran sudah bisa diatur sesuai keinginan masing-masing (Lintong, 2015). Model ini lebih dapat diterima oleh gaya hidup masyarakat terkini (Pradianingtyas, 2015; Dzulfiqar, 2016). Dampaknya, secara luas, puluhan hingga ratusan agen perjalanan konvensional yang mengandalkan model tradisional harus mati suri hingga gulung tikar akibat beralihnya para traveler menggunakan OTA.

Sebagaimana yang penulis kutip dari laman online kontan.co.id, berdasarkan penjelasan wakil ketua umum Asosiasi Travel Agent Indonesia (ASTINDO), hingga akhir bulan Januari 2019 diprediksi tidak kurang dari 3\% anggotanya dinyatakan bangkrut. Hitungan ini belum termasuk agen perjalanan yang tidak tergabung dalam ASTINDO yang sudah menutup bisnisnya mencapai jumlah ratusan. Lebih jauh, berdasarkan data teraktual yang diungkapkan sekretaris umum ASTINDO dalam kumparan.co.id, hingga bulan Maret 2019 
jumlah agen perjalanan yang tutup di daerah Jakarta saja mencapai 50\% dan untuk yang di luar Jakrta berada diangka 40\%. Sementara agen perjalanan konvensional yang masih eksis mencoba untuk bertahan di tengah badai sembari mencoba mencari ceruk bisnis yang belum terjamah sebagai tempat berlabuh. Agen perjalanan konvensional bukannya tidak mencoba untuk mengejar ketertinggalannya. Berbagai daya dan upaya telah dilakukan untuk dapat mengimbangi laju bisnis dan teknologi yang diterapkan oleh OTA. Beberapa agen perjalanan konvensional juga mulai merambah e-commerce untuk memperluas jangkauan pemasarannya. Namun tetap saja, dominasi teknologi serta kekuatan finansial yang dimiliki OTA dengan backup para investor besar dibelakangnya belum mampu diimbangi para agen perjalanan konvensional. Sementara untuk melakukan riset dan pengembangan bisnis, pemasaran, dan teknologi tentunya membutuhkan dana yang cukup fantastis. Perubahan strategi bisnis mutlak harus dilakukan oleh agen perjalanan konvensional untuk tetap dapat bertahan di era industri 4.0.

Dari ranah akademik, isu strategi bersaing para agen perjalanan konvensional ditengah gempuran OTA menjadi pembahasan yang selalu menarik untuk diperbincangkan. Berbagai penelitian cukup sering membahas terkait strategi manajemen agen perjalanan konvensional dalam pengembangan bisnis, pemasaran, perilaku konsumen hingga strategi untuk bertahan (lihat Lintong, 2015; Diwati dan Santoso, 2015; Athar, 2016; Sari dkk., 2016; Harsanti dkk., 2017; Anjastari dan Dewantara, 2017). Benang merah yang dapat penulis tarik dari setiap peneltian terdahulu adalah inovasi dan adaptasi dengan memanfaatkan keunggulan di setiap daerah masing-masing yang belum terjamah oleh OTA menjadi kunci untuk agen perjalanan konvensional agar dapat terus bertahan. Penelitian ini sendiri penulis tujukan untuk mengeksplorasi lebih jauh strategi bisnis yang harus dikembangkan oleh agen perjalanan konvensional agar dapat tetap menjalankan bisnisnya berdampingan dengan OTA. Penulis menetapkan PT Jasa Nusa Wisata (Jatatur) yang berada di Pulau Lombok sebagai objek dalam penelitian ini. 
Alasan pemilihan PT Jasa Nusa Wisata dikarenakan perusahaan ini merupakan salah satu perusahaan agen perjalanan tertua di Pulau Lombok yang telah berdiri sejak tahun 1997. Dengan segudang pengalamannya dalam beradaptasi di dua dekade perkembangan bisnis agen perjalanan, penulis harap dapat memberikan khasanah tersendiri bagi hasil penelitian nantinya. Apalagi lokasi perusahaan berada di Pulau Lombok dimana pulau yang bertetanggaan dengan Pulau Bali ini merupakan destinasi wisata yang sedang berkembang pesat dalam 10 tahun terakhir. Selain mendapatkan privilege dari pemerintah pusat dengan ditetapkannya wilayah pantai selatan sebagai Kawasan Ekonomi Khusus (KEK), masuknya investasi dari Dorna Sport selaku penyelenggara dari ajang bergengsi MotoGP dan Super Bike juga semakin menarik minat pelancong dari seluruh dunia untuk berkunjung ke Pulau Seribu Masjid. Harapan yang digantungkan adalah dengan munculnya Pulau Lombok sebagai destinasi wisata internasional akan mampu menggeliatkan perekonomian masyarakat, khususnya lagi bisnis masyarakat lokal yang bergerak di bidang hospitality industry. Oleh karena itu penguatan bisnis lokal, seperti PT. Jasa Nusa Wisata, menjadi sangat diperlukan agar dapat berperan aktif dalam perkembangan ini. Menjadi hal yang menggelikan tentunya apabila meningkatnya jumlah wisatawan dan berkembangnya destinasi wisata di Pulau Lombok tidak diikuti dengan keterlibatan para pelaku usaha lokal.

Berdasarkan latar belakang tersebut maka peneliti tertarik mengajukan penelitian dengan judul "Strategi bersaing agen perjalanan konvensional di era digital: Studi pada PT. Jasa Nusa Wisata”. Masalah penelitian yang penulis angkat adalah bagaimana PT. Jasa Nusa Wisata mengembangkan strategi bisnisnya agar dapat mempertahankan eksistensinya di tengah superioritas OTA. Tujuan dari penelitian ini adalah untuk mengidentifikasi faktor-faktor kunci baik eksternal dan internal dari perusahaan kemudian merumuskan strategi bersaing yang tepat menggunakan analisis SWOT yang dikombinasikan dengan matriks internal eksternal (IE). Manfaat dari penelitian ini diharapkan dapat menjadi referensi bagi perusahaan-perusahaan sejenis untuk mengembangkan strategi keunggulan 
bersaing serta menjadi rujukan bagi peneliti-peneliti selanjutnya dalam ranah manajemen strategik.

\section{METODE PENELITIAN}

Penelitian ini adalah penelitian studi kasus yang merupakan pendekatan dalam ranah penelitian kualitatif yang bertujuan untuk mengeksplorasi kehidupan nyata, sistem terbatas kontemporer (kasus) atau beragam sistem terbatas (berbagai kasus), melalui pengumpulan data yang detail dan mendalam yang melibatkan beragam sumber informasi atau sumber informasi majemuk seperti observasi, wawancara, bahan audiovisual, dan dokumen serta berbagai laporan (Creswell, 2015). Penjelasan yang ditawarkan oleh Yin (2015) bahkan lebih spesifik dengan mengatakan bahwa studi kasus merupakan metode yang lebih cocok bila pokok pertanyaan suatu penelitian berkenaan dengan how dan why, bila peneliti hanya memiliki sedikit peluang untuk mengontrol peristiwa-peristiwa yang akan diselidiki, dan bilamana fokus penelitiannya terletak pada fenomena kontemporer (masa kini) di dalam konteks kehidupan nyata.

Situs penelitian yang akan diteliti adalah PT. Jasa Nusa Wisata yang terletak di Jalan Panca Usaha, Kompleks Pertokoan Cilinaya Blok A/12, Kota Mataram, Lombok yang sekaligus juga merupakan Kantor Pusat perusahaan. Hal ini akan memudahkan penulis dalam mengeksplorasi dan mendiskusikan setiap permasalahan dan solusi yang dibutuhkan dengan para jajaran manajemen inti perusahaan. Penentuan informan dalam penelitian ini menggunakan non probability sampling dengan metode purposive sampling. Non probability sampling adalah tekhnik pengambilan informan yang tidak memberi peluang atau kesempatan yang sama bagi setiap unsur atau anggota populasi untuk dipilih menjadi informan, sedangkan metode purposive sampling adalah teknik pengambilan informan dengan pertimbangan tertentu misalnya orang yang dipilih menjadi informan tersebut dianggap paling mengerti tentang apa yang ingin peneliti cari sehingga akan memudahkan untuk meneliti obyek atau situasi sosial yang akan diteliti (Sugiyono, 2014). Dalam penelitian ini metode purposive 
sampling akan diberlakukan kepada informan yang berperan sebagai perancang strategi dan pengambil keputusan dalam perusahaan yaitu direktur utama, manajer penjualan dan manajer pemasaran.

Teknik pengumpulan data yang digunakan untuk mengumpulkan informasi yang dibutuhkan oleh penulis adalah wawancara dan dokumentasi. Khususnya teknik wawancara, akan menjadi ujung tombak penulis untuk menjawab masalah penelitian ini karena dari hasil wawancara dengan para informan selanjutnya akan didiskusikan lebih mendalam untuk menemukan jawaban penelitian yang diharapkan. Sementara teknik dokumentasi akan menjadi pendukung untuk melengkapi data-data penelitian berdasarkan dokumendokumen perusahaan.

Prosedur analisis data dalam penelitian ini penulis bagi ke dalam beberapa langkah. Pertama, adalah dengan mengidentifikasi faktor faktor kekuatan dan kelemahan (Faktor Internal) serta faktor-faktor peluang dan ancaman (Faktor Eksternal). Kedua, faktor-faktor tersebut kemudian diberikan skor menggunakan Matriks IFE (internal factor evaluation) dan EFE (eksternal faktor evaluation) berdasarkan penilaian pihak manajemen perusahaan. Ketiga, berdasarkan skor yang didapatkan dari matriks EFE dan IFE selanjutnya akan digunakan untuk mengetahui posisi bersaing perusahaan menggunakan matriks IE (internal eksternal). Keempat, setelah posisi bersaing perusahaan diketahui, selanjutnya adalah merumuskan strategi yang harusnya dilakukan oleh perusahaan dengan menggunakan Analisis Matriks SWOT. Terakhir adalah pembahasan strategi dengan mengemukakan alasan logis dibalik pengambilan setiap strategi bersaing.

\section{HASIL DAN PEMBAHASAN}

Berdasarkan hasil wawancara yang penulis lakukan dengan pihak PT. Jasa Nusa Wisata, diidentifikasikan beberapa faktor-faktor strategi internal dan eksternal yang terdiri dari sembilan faktor kekuatan (strengths), enam faktor kelemahan (weaknesses), delapan faktor peluang (opportunities) dan enam faktor ancaman (threats). Faktor-faktor yang telah diidentifikasikan tersebut kemudian 
penulis susun ke dalam tabel IFE (internal factor evaluation) dan tabel EFE (eksternal factor evaluation) untuk dilakukan penilaian. Penilaian sendiri dilakukan oleh pihak perusahaan berdasarkan pendapat mereka atas pengaruh kekuatan setiap faktor-faktor tersebut terhadap kondisi perusahaan.

Tabel 1:

Tabel IFE PT. Jasa Nusa Wisata

\begin{tabular}{|c|c|c|c|}
\hline Faktor strategi internal & Bobot & Rating & Skor \\
\hline \multicolumn{4}{|l|}{ Kekuatan } \\
\hline $\begin{array}{l}\text { 1. Hubungan kemitraan dengan berbagai instansi } \\
\text { pemerintah dan swasta di wilayah NTB }\end{array}$ & 0.075 & 3.5 & 0.2625 \\
\hline 2. Basis pelanggan tradisional yang masih kuat & 0.070 & 3.0 & 0.21 \\
\hline 3. Budaya Organisasi yang baik & 0.045 & 2.0 & 0.09 \\
\hline 4. Brand lebih dikenal & 0.065 & 2.0 & 0.13 \\
\hline 5. Jaringan pemasaran offline dan online & 0.065 & 2.5 & 0.13 \\
\hline 6. Tersedianya jaringan komunikasi aktif dengan pelanggan & 0.060 & 3.0 & 0.18 \\
\hline 7. Tema promosi yang beragam & 0.070 & 3.5 & 0.245 \\
\hline 8. Paket perjalanan wisata yang bervariasi & 0.065 & 3.0 & 0.195 \\
\hline 9. Kondisi permodalan cukup memadai & 0.065 & 3.0 & 0.195 \\
\hline Total Faktor Kekuatan & 0.580 & & 1.6375 \\
\hline \multicolumn{4}{|l|}{ Kelemahan } \\
\hline 1. Belum memiliki visi dan misi secara tertulis & 0.070 & 2.0 & 0.14 \\
\hline 2. Belum ada SOP perusahaan secara tertulis & 0.070 & 3.0 & 0.21 \\
\hline 3. SDM bagian pemasaran sangat terbatas & 0.075 & 3.5 & 0.2625 \\
\hline 4. Perekrutan SDM masih secara tradisional & 0.070 & 2.5 & 0.175 \\
\hline 5. Sentralistik & 0.060 & 3.0 & 0.18 \\
\hline 6. Harga Produk relatif tinggi dalam industri sejenis & 0.075 & 3.5 & 0.2625 \\
\hline Total Faktor Kelemahan & 0.420 & & 1.23 \\
\hline Total IFE & 1 & & 2.8675 \\
\hline
\end{tabular}

Tabel 2:

Tabel EFE PT. Jasa Nusa Wisata

\begin{tabular}{lccc}
\hline Faktor strategi eksternal & Bobot & Rating & Skor \\
\hline Peluang & & & \\
1. Destinasi wisata di daerah NTB berkembang pesat & 0.075 & 4.0 & 0.30 \\
2. Jumlah destinasi wisata di daerah NTB meningkat & 0.070 & 3.5 & 0.245 \\
3. Tren wisata halal meningkat & 0.070 & 3.0 & 0.21 \\
4. Pulau lombok menjadi hub Air Asia dari mancanegara & 0.080 & 3.0 & 0.24 \\
5. Jumlah penerbangan langsung dari & & 2.5 & 0.1625 \\
meningkat & & \\
6. Situasi keamanan wilayah NTB yang semakin kondusif & 0.070 & 3.5 & 0.245 \\
7. Masyarakat NTB semakin sadar wisata & 0.070 & 2.5 & 0.175 \\
8. Meningkatnya permintaan terhadap layanan private tour & 0.060 & 2.5 & 0.15 \\
\hline
\end{tabular}




\begin{tabular}{lccc}
\hline Total Faktor Peluang & 0.560 & & 1.7275 \\
\hline Ancaman & & & \\
1. Agen perjalan berbasis aplikasi semakin superior & 0.085 & 4.0 & 0.34 \\
2. Munculnya agen perjalanan konvensional baru di daerah & 0.065 & 2.5 & 0.1625 \\
NTB & & & \\
3. Harga tiket pesawat yang cenderung meningkat & 0.075 & 3.5 & 0.2625 \\
4. Belum pulihnya kondisi psikologis masyarakat akibat & 0.065 & 3.0 & 0.195 \\
$\quad$ bencana gempa & & & \\
5. Perekonomian nasional stagnan & 0.075 & 3.0 & 0.225 \\
6. Fee dari maskapai semakin menurun & 0.075 & 3.5 & 0.2625 \\
\hline Total Faktor Ancaman & 0.440 & & 1.4475 \\
\hline Total IFE & 1 & & 3.175 \\
\hline
\end{tabular}

Berdasarkan penilaian yang telah dilakukan bersama dengan pihak perusahaan, diketahui bahwa faktor kekuatan (strengths) memiliki total skor sebesar 1,6375 dan faktor kelemahan (weaknesses) memiliki total skor sebesar 1,23. Dengan demikian, total skor dari tabel IFE sebesar 2,8675. Sementara dari sisi eksternal, faktor peluang (opportunities) memiliki total skor sebesar 1,7275 dan faktor ancaman (threats) memiliki total nilai sebesar 1,4475, sehingga total skor yang didapatkan untuk tabel EFE sebesar 3,175. Total nilai tertimbang yang didapatkan dari tabel IFE dan tabel EFE menempatkan posisi PT. Jasa Nusa Wisata berada pada kuadran II dalam matriks Internal Eksternal (IE). Mengacu pada Anthony dan Govindarajan (2007), maka posisi perusahaan berada dalam peta persaingan industri agen perjalanan cukup kuat. Strategi yang tepat dalam posisi ini adalah investasi dan pengembangan secara selektif.

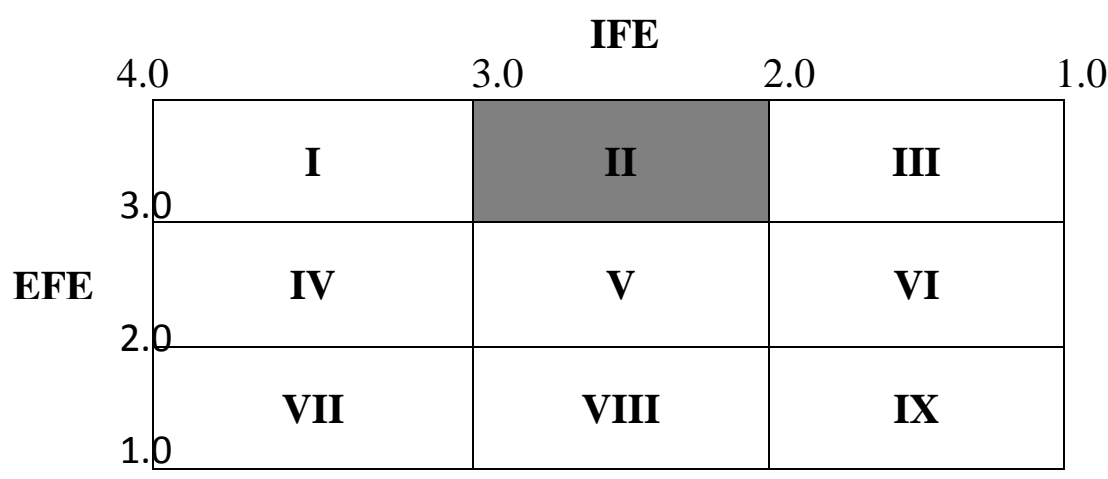

Gambar 1. Analisis Matriks IE PT Jasa Nusa Wisata 
Setelah posisi bersaing perusahaan diketahui melalui analisis tabel IFE, tabel EFE dan matriks IE, maka selanjutnya adalah merumuskan strategi alternatif yang mendukung kegiatan perusahaan dalam pengembangan secara selektif dan investasi dengan menggunakan analisis matriks SWOT.

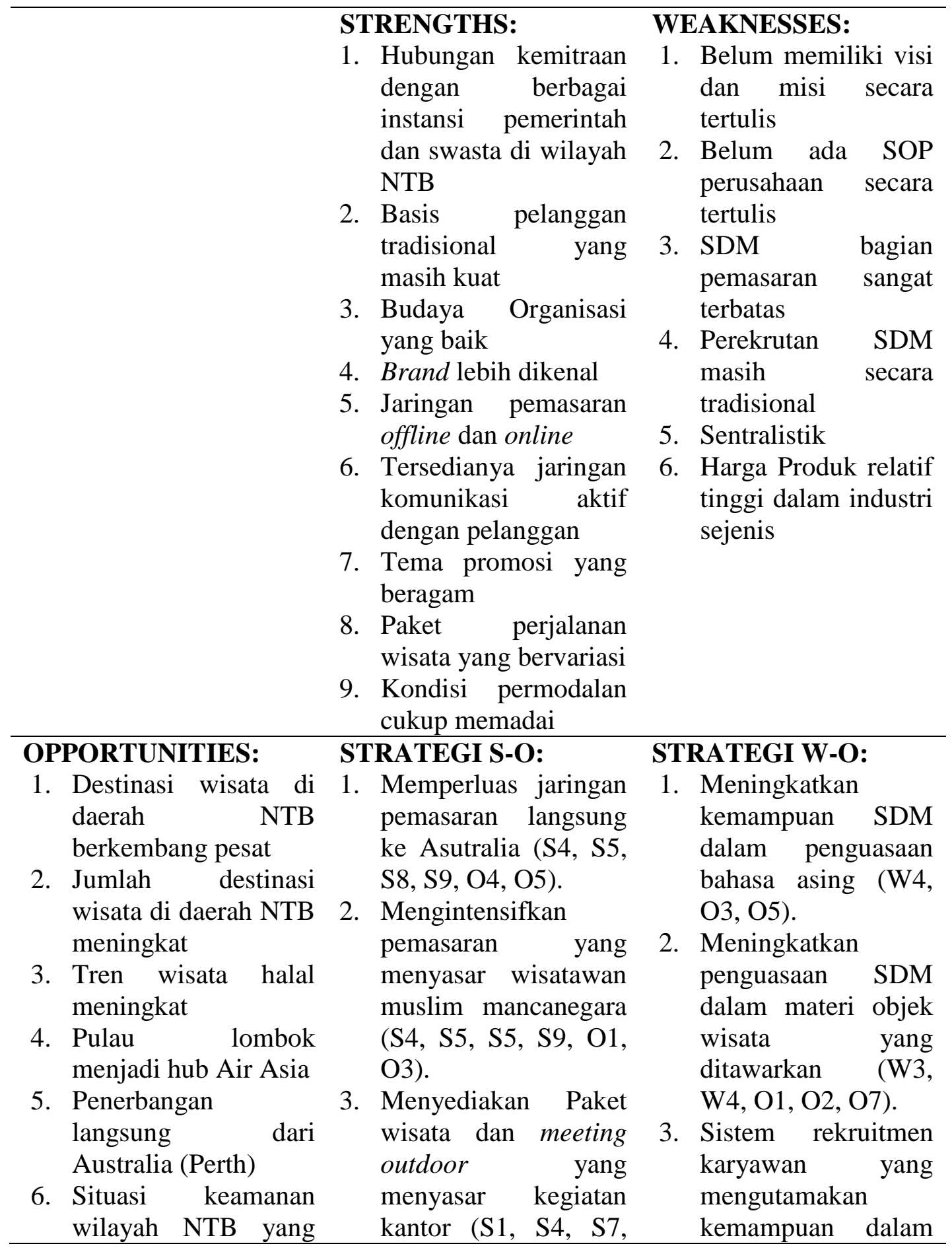




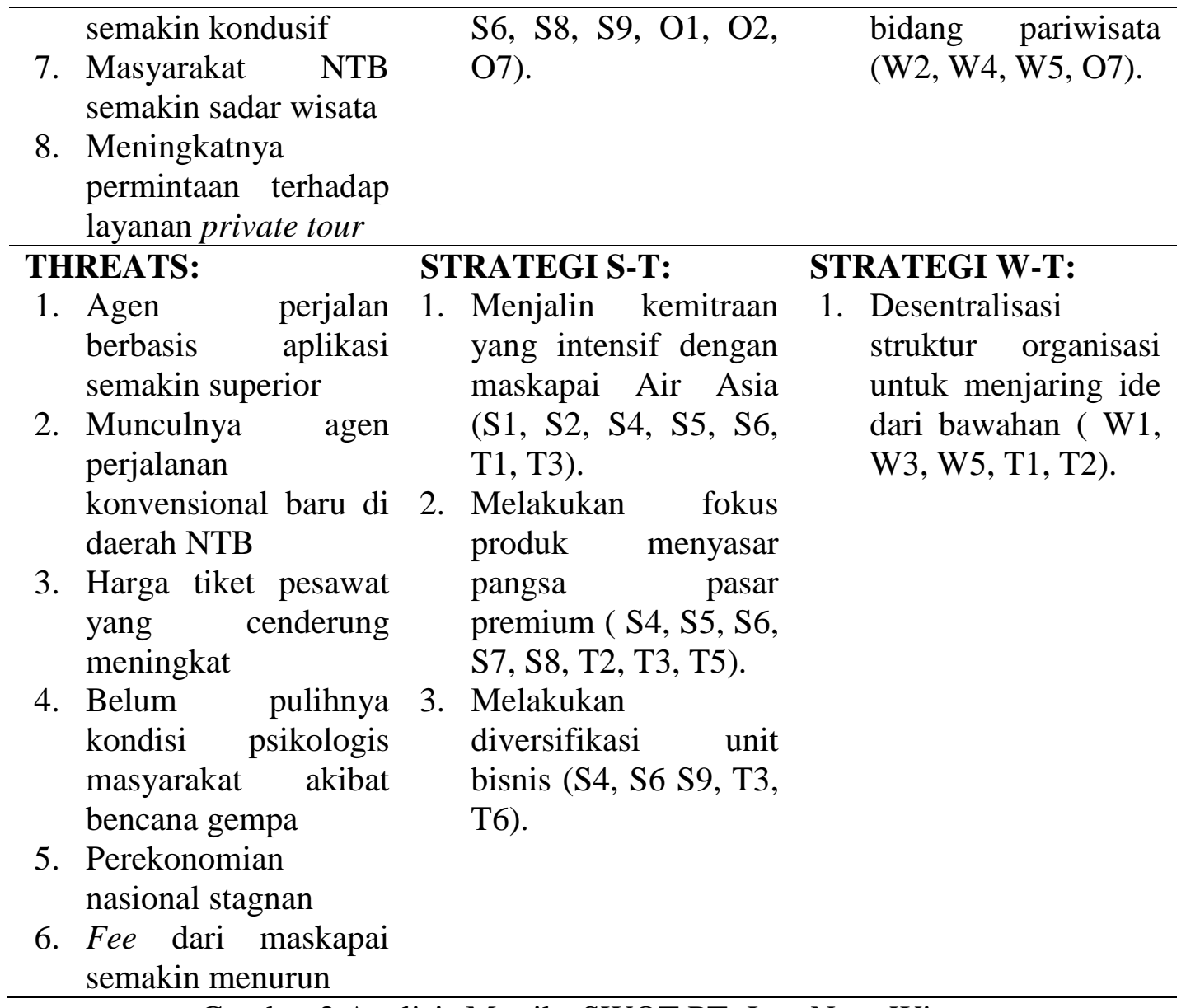
Gambar 2.Analisis Matriks SWOT PT. Jasa Nusa Wisata

Berdasarkan pengembangan strategi dengan menggunakan analisis matriks SWOT, diperoleh 10 strategi bersaing yang dapat dilakukan oleh PT. Jasa Nusa Wisata untuk meningkatkan posisi bersaingnya dalam industri agen perjalanan. Strategi-strategi tersebut terdiri dari 3 strategi S-O, 3 strategi W-O, 3 strategi S-T dan 1 strategi W-T. Pembahasan logis atas munculnya setiap strategi di atas adalah sebagai berikut:

1. Memperluas Jaringan Pemasaran Langsung Ke Australia

Dipilihnya Pulau Lombok oleh maskapai Air Asia sebagai hub di wilayah Indonesia tengah ditandai dengan dibukanya rute penerbangan langsung Perth-Lombok. Kondisi ini akan meningkatkan jumlah wisatawan yang datang secara langsung dari Ibukota Negara Bagian Australia Barat tersebut. Peluang ini perlu diperhatikan oleh PT. Jasa Nusa 
Wisata untuk memasarkan produknya, terutama paket perjalanan, secara aktif kepada masyarakat disana. Hal tersebut memang membutuhkan dana yang tidak sedikit, namun mengingat bahwa Perth memiliki populasi sekitar 2 Juta jiwa, potensi keuntungan jangka panjang dari pelaksanaan strategi ini penulis anggap sepadan. Apalagi Pulau Lombok memiliki citra positif di mata masyarakat Australia yang menyebabkan Pulau Lombok menjadi destinasi Favorit wisatawan Australia di Indonesia setelah Pulau Bali.

2. Mengintensifkan pemasaran yang menyasar wisatawan muslim mancanegara.

Kemenangan Pulau Lombok dalam ajang World Halal Travel Summit pada tahun 2015 telah mengangkat Pulau lombok dalam peta persaingan destinasi wisata halal dunia. Citra sebagai destinasi wisata yang ramah wisatawan muslim tentunya akan menarik minat wisatawan muslim khususnya yang berasal dari malaysia, brunei darusalam, serta kawasan timur tengah. Peluang ini dapat dimanfaatkan oleh PT. Jasa Nusa Wisata untuk mendatangakan lebih banyak wisatawan muslim dengan menawarkan paket perjalanan wisata yang berorientasi pada budaya, religi, maupun memanfaatkan Ramadhan Expo yang setiap tahunnya secara rutin dilaksanakan oleh Pemerintah Provinsi NTB.

3. Menyediakan Paket wisata dan meeting outdoor yang menyasar kegiatan kantor.

Perkembangan dunia kerja modern ini mengalami perubahan dari sisi budaya kerja. Kerja tidak lagi diidentikan dengan selalu berada dibelakang meja dengan tumpukan kertas tugas yang menunggu deadline untuk diselesaikan. Budaya kerja modern ini lebih fleksibel ditandai dengan meningkatnya kesadaran bahwa pekerjaan dapat dilakukan bersamaan dengan rekreasi. Oleh karena itu saat ini tidak jarang kegiatan kantor seperti rapat serta pelatihan dilakukan di objek wisata yang juga dipadukan dengan family gathering serta kegiatan outbond. Mengingat bahwa PT. Jasa Nusa Wisata memiliki mitra dari instansi pemerintah dan 
swasta yang cukup banyak, maka hal ini perlu dimanfaatkan oleh perusahaan dengan menawarkan paket meeting outdor. Apalagi saat ini objek wisata di Pulau Lombok sangat beragam serta didukung oleh sarana dan prasarana yang cukup memadai untuk dilakukannya hal tersebut.

4. Meningkatkan kemampuan SDM dalam penguasaan bahasa asing

Strategi ini merupakan follow up dari strategi pertama dan kedua. Untuk meningkatkan penjualan produk yang menyasar wisatawan mancanegara, SDM yang dimiliki oleh PT. Jasa Nusa Wisata tentunya harus mendukung untuk berkomunikasi dengan target konsumen. Hal ini akan memudahakan tersampaikannya konten tentang produk-produk yang ditawarkan oleh perusahaan secara maksimal kepada calon konsumen.

5. Meningkatkan penguasaan SDM dalam materi objek wisata yang ditawarkan

Selain memiliki skill berkomunikasi dalam bahasa asing, penguasaan materi tentang objek-objek wisata yang ditawarkan perlu menjadi perhatian. Para wisatawan tentunya akan bertanya, mengapa saya harus mengunjungi objek wisata tersebut?. SDM yang berhadapan langsung dengan calon konsumen harus mampu menjelaskan setiap keunikan yang ditawarkan oleh objek wisata yang akan dituju. Informasi yang disampaikan kepada calon konsumen akan mempengaruhi tingkat ketertarikan konsumen untuk mengunjungi objek wisata yang ditawarkan.

6. Sistem rekruitmen karyawan yang mengutamakan kemampuan dalam bidang pariwisata

Sistem rekruitmen karyawan yang saat ini diterapkan oleh PT Jasa Nusa Wisata sebagaimana yang diakui oleh Mr. JO selaku Direktur Utama perusahaan masih menggunakan sistem tradisional. Sistem Tradisional yang dimaksud adalah karyawan yang direkrut umumnya merupakan kolega dari orang-orang yang dekat dengan petinggi perusahaan. Selain itu, banyak dari karyawan tetap yang ada saat ini dulunya merupakan karyawan magang yang kinerjanya dinilai baik oleh perusahaan. Hal ini sedikit banyak akan mempengaruhi tingkat kualitas SDM yang ada karena 
belum dapat dipastikan apakah karyawan tersebut memiliki kompetensi di Bidang Pariwisata. Bisnis pariwisata tidaklah sama dengan bisnis manufaktur atau jasa pada umumnya. Bisnis ini membutuhkan ide yang brilian disetiap kegiatannya. Penulis sendiri menyarankan setiap karyawan di setiap lini perusahaan memiliki latar belakang bidang pariwisata baik itu dari segi pendidikan maupun pengalaman kerja. Hal ini akan sangat membantu PT Jasa Nusa Wisata dalam menjaring ide-ide untuk keberlanjutan kegiatan perusahaan.

7. Menjalin kemitraan yang intensif dengan maskapai Air Asia

Dalam dunia bisnis, skema kerjasama $B$ to $B$ (business to business) adalah hal yang lumrah dilakukan. Selain untuk memperkuat posisi strategis, skema ini juga dapat memperluas jaringan pemasaran untuk menggaet konsumen baru. Kerjasama dengan maskapai Air Asia merupakan ceruk bisnis baru yang harus dipertimbangkan oleh PT. Jasa Nusa Wisata mengingat untuk penjualan tiket maskapai nasional telah dikuasai oleh agen perjalanan berbasis aplikasi / OTA. Sementara untuk penjualan tiket Air Asia belum disediakan hingga saat ini oleh OTA.

8. Melakukan fokus produk menyasar pangsa pasar premium

Ditengah bersaing ketatnya bisnis agen perjalanan, perekonomian secara nasional justru tampak stagnan yang menyebabkan kurang meningkatnya daya beli masyarakat kelas menengah termasuk dalam mengagendakan perjalanan wisata. Masalah tersebut semakin diperparah dengan naiknya harga tiket pesawat maskapai nasional. Sedikit banyak kondisi ini mempengaruhi tingkat penjualan produk perusahaan karena mayoritas pelanggan berasal dari kalangan ekonomi kelas menengah. Untuk menyiasati hal ini, strategi fokus dapat dijalankan oleh PT Jasa Nusa Wisata untuk menyasar wisatawan kalangan menengah ke atas dengan menawarkan paket perjalanan wisata premium. Apalagi saat ini Pulau Lombok sudah memiliki beberapa hotel berbintang 4 dan 5, even berskala nasional dan internasional serta destinasi wisata kelas atas yang dapat mendukung untuk dilaksanakannya strategi ini. 
9. Melakukan diversifikasi unit bisnis

Keluhan terhadap menurunnya fee dari maskapai atas penjualan tiket hampir terjadi di setiap agen perjalanan di Indonesia. Seperti yang diungkapkan Mr. JO selaku Direktur Utama dari PT. Jasa Nusa Wisata, penurunan fee ini berimplikasi pada keuntungan dari penjualan tiket penerbangan semakin menurun. Apalagi menurunnya tingkat pembelian tiket pesawat akibat naiknya harga tiket semakin memperparah kondisi ini. Penjualan tiket pesawat tidak bisa lagi diandalkan untuk untuk menjaga keberlangsungan operasional perusahaan. Oleh karena itu, perusahaan agen perjalanan perlu memutar otak untuk mencari sumber pendapatan lainnya. Strategi yang dapat dilakukan untuk mengatasi kondisi ini adalah melakukan pengembangan unit bisnis melalui diversifikasi usaha. Saat ini, PT. Jasa Nusa Wisata sudah memiliki beberapa unit bisnis selain penjualan tiket pesawat, seperti jasa travel dan paket wisata. Satu hal lagi yang sekiranya dapat dilakukan oleh perusahaan misalnya dengan membuka jasa pengiriman barang. Hal ini penulis sarankan karena kondisi yang terjadi sekarang yaitu adanya kebijakan bagasi berbayar yang dilakukan oleh salah satu maskapai low cost carrier nasional, Lion Air, yang menyebabkan enggannya wisatawan membawa barang dalam jumlah berlebih. Padahal maskapai ini merupakan maskapai yang paling populer digunakan oleh masyarakat Indonesia dalam melakukan perjalanan. Kondisi ini secara langsung berpengaruh pada penurunan tingkat penjualan oleh-oleh dan souvenir di Pulau Lombok. Peluang ini perlu diperhatikan oleh perusahaan untuk menyediakan jasa pengiriman barang baik untuk memfasilitasi kebutuhan para pelanggannya.

10. Melakukan desentralisasi struktur organisasi

Persaingan dalam industri agen perjalan yang semakin ketat mengharuskan perusahaan untuk terus berinovasi dalam produk yang ditawarkan. Perusahaan harus mampu menyerap setiap ide kreatif dalam karyawannya untuk terus dapat menghasilkan produk yang inovatif. Salah satu cara dalam memaksimalkan potensi tersebut adalah dengan 
melakukan desentralisasi struktur organisasi. Pada perusahaan yang desentralistik, setiap karyawan memiliki peran dalam memberikan pendapat dan masukan atas setiap kegiatan perusahaan termasuk dalam menentukan target dan variasi produk. Berdasarkan pendapat dari pihak PT Jasa Nusa Wisata, saat ini keputusan-keputusan perusahaan masih terkonsentrasi pada manajer level atas, khususnya Direktur Utama. Hal ini menyebabkan kurangnya penjaringan ide di karyawan level bawah, terutama sekali karyawan yang berada di lapangan dimana dalam posisi ini karyawan berinteraksi langsung dengan customer. Perusahaan harus mampu menyediakan media penjaringan ide untuk memaksimalkan kreativitas karyawan dalam menghasilkan produk-produk inovatif.

\section{KESIMPULAN}

Persaingan yang semakin ketat dalam industri agen perjalanan yang melibatkan agen perjalanan konvensional dan agen perjalanan berbasis aplikasi (OTA) akibat perkembangan teknologi informasi perlu disikapi dengan inovasiinovasi yang berkelanjutan untuk menghasilkan produk-produk yang memiliki nilai tambah bagi perusahaan. Perumusan strategi bersaing menjadi perlu untuk dilakukan agar dapat memetakan posisi perusahaan di dalam industri yang selanjutnya diikuti dengan penyusunan program-program inovatif untuk dapat menjaga keberlangsungan perusahaan dalam bisnis yang bersangkutan. Penelitian ini dilakukan pada PT. Jasa Nusa Wisata yang berkantor pusat di Pulau Lombok. Dari hasil data lapangan yang diperoleh melalui wawancara dan dokumentasi dengan pihak karyawan, diidentifikasikan beberapa faktor-faktor strategi internal dan eksternal yang terdiri dari sembilan faktor kekuatan (strengths), enam faktor kelemahan (weaknesses), delapan faktor peluang (opportunities) dan enam faktor ancaman (threats). Faktor-faktor tersebut kemudian dirangkum dalam tabel IFE dan EFE yang menghasilkan total skor sebesar 2,8675 untuk tabel IFE serta total skor sebesar 3,175 untuk tabel EFE. Hasil penilaian ini menempatkan perusahaan 
di kuadran II dalam mariks IE. Strategi yang tepat dalam posisi tersebut adalah investasi atau pengembangan secara selektif.

Setelah mengetahui posisi bersaing perusahaan berdasarkan matriks IE, selanjutnya informasi tersebut menjadi masukan dalam pengembangan strategi alternatif menggunakan analisis matriks SWOT. Dari hasil analisis matriks SWOT, diperoleh 10 strategi bersaing yang secara garis besar merangkum kegiatan investasi dan pengembangan secara selektif. Startegi-strategi tersebut adalah: memperluas jaringan pemasaran langsung ke Australia, mengintensifkan pemasaran yang menyasar wisatawan muslim mancanegara, menyediakan paket wisata dan meeting outdoor yang menyasar kegiatan kantor, meningkatkan kemampuan SDM dalam penguasaan bahasa asing, meningkatkan penguasaan SDM dalam materi objek wisata yang ditawarkan, sistem rekruitmen karyawan yang mengutamakan kemampuan dalam bidang pariwisata, menjalin kemitraan yang intensif dengan maskapai Air Asia, melakukan fokus produk menyasar pangsa pasar premium, melakukan diversifikasi unit bisnis dan yang terakhir adalah melakukan desentralisasi struktur organisasi.

Penelitian ini sendiri penulis sadari masih memiliki keterbatasan terutama dalam hal penggunaaan instrumen pengembangan strategi. Penelitian ini hanya menggunakan analisis IFE, EFE, matriks IE, dan matriks SWOT yang terbatas pada pengembangan strategi alternatif. Untuk penelitian selanjutnya dapat menggunakan variasi lain dari instrumen perumusan strategi alternatif seperti Matriks SPACE (Strategic Position and Action Evaluation), matriks BCG (Boston Consulting Group) ataupun matriks Grand Strategy yang kemudian dikombinasikan dengan Matriks QSPM (Quantitative Strategic Planning Matrix) untuk lebih mengerucutkan strategi alternatif ke dalam strategi prioritas. 


\section{DAFTAR RUJUKAN}

Anjastantri, W., \& Dewantara, R. Y. (2017). Mempertahankan Eksistensi Traditional Travel Agency dalam Menghadapi Ancaman Online Travel Agency. Jurnal Administrasi Bisnis (JAB), Vol. 50 No. 6, 151-156.

Athar, H. S. (2016). Analisis Strategi Pemasaran Jasa Pada PT. Mari Sana Ticket Station Mataram. Conference on Management and Behavioural Studies (pp. 535-543). Jakarta: Universitas Tarumanegara.

Creswell, J. W. (2015). Penelitian Kualitatif \& Desain Riset: Memilih Di Antara Lima pendekatan (3 ed.). (A. L. Lazuardi, Trans.) Yogyakarta: Pustaka Pelajar.

Diwati, F., \& Santoso, T. I. (2015). Pengaruh Strategi Intergrated Marketing Communication (IMC) Terhadap Keputusan Membeli Konsumen pada Bisnis Tour \& Travel di Wilayah Daerah Istimewa Yogyakarta. Jurnal EBBANK, Vol. 6 No. 2, 33-54.

Dzulfiqar, R. A. (2016). Pengaruh Online Travel Agent Terhadap Travel Agent Konvensional di Kota Bandung. Bandung: Sekolah Tinggi Pariwisata.

Harsanti, P. K., Dewi, N. I., \& Sukartini, N. W. (2017). Strategi Bersaing dengan Online Travel Agent (OTA) Menggunakan Pendekatan SWOT Analysis pada PT Mitra Global Holiday Bali, Unit Usaha MG Bedbank. Jurnal Bisnis dan Kewirausahaan, Vol. 13 No. 3, 166-175.

Kontan.co.id. (2019, Januari 31). Retrieved September 2019, from https://industri.kontan.co.id/news/astindo-100-perusahaan-travel-agentutup-karena-kalah-saing-dengan-online

Kumparan.com. (2019, Maret 15). Retrieved September 2019, from https://kumparan.com/kumparanbisnis/digempur-online-travel-agentkonvensional-terancam-gulung-tikar-1552620295839080289

Lintong, N. N. (2015). Strategi Bersaing Biro Perjalanan Wisata Alindo Dewata Tours Bali. JUMPA, Vol 2 No 1, 117-131.

Pradiatiningtyas, D. (2015). Analisa Buying Behavior pada Online Travel Agent. Jurnal Khasanah Ilmu, Vol. 6 No. 2, 56-61.

Sari, A. P., Negara, I. M., \& Suardana, I. W. (2016). Strategi Pemasaran Paket Wisata Melalui Media Online di Trully Asia Tour and Travel. Jurnal IPTA , Vol. 4 No. 1, 74-78.

Sugiyono. (2014). Memahami Penelitian Kualitatif. Bandung: Alfabeta.

Yin, R. K. (2015). Studi kasus: Desain Dan Metode. (M. D. Mudzakir, Trans.) Depok: PT. Rajagrafindo Persada. 